\title{
Individual Plant Treatments for Controlling Redberry Juniper Seedlings
}

\author{
D.N. UECKERT AND S.G. WHISENANT
}

\begin{abstract}
Cutting at the soil surface or hand grubbing to a depth of 5 to 15 cm completely controlled redberry juniper seedlings that averaged $34 \mathrm{~cm}$ in height in the southwestern Edwards Plateau of Texas. Foliar sprays (0.5\% a.i.) of bromacil, hexazinone, 2,4,5T + picloram (1:1), and picloram in water carriers as well as picloram in a 2:98 (v:v) diesel fuel/water emulsion applied in fall or spring also completely controlled juniper seedlings. Foliar sprays of dicamba $(0.5 \%$ a.i.) completely controlled redberry juniper seedlings in a wet spring and $76 \%$ of the seedlings in a dry fall. Pelleted or granular formulations of dicamba, tebuthiuron, and picloram at 2.2 to $4.5 \mathrm{~kg}(\mathrm{a} . \mathrm{i}.) / \mathrm{ha}$ as individual-plant treatments did not satisfactorily control juniper seedlings in a dry fall or a wet spring. Cutting or hand grubbing were the least cost alternatives (\$23.14/ha), based on 1979 prices for controlling stands averaging over $2,000 /$ ha. Dicamba as a $0.5 \%$ foliar spray was the least cost herbicide spray evaluated ( $\$ 28.24 / \mathrm{ha})$, followed closely by bromacil (\$29.28/ha), hexazinone (\$32.10/ha), and 2,4,5-T + piclo$\operatorname{ram}(\$ 32.44 / \mathrm{ha})$.
\end{abstract}

Junipers (Juniperus spp.) infested 7.3 million ha of Texas rangeland in 1949 (Allred 1949). This acreage had increased to 8.7 million ha by 1964 (Smith and Rechenthin 1964). Over 40 million ha of rangeland in the United States was infested with juniper in 1964 (Allred 1964). Redberry juniper (J. pinchotii Sudw.) is recognized as a primary brush problem on Texas rangeland, particularly on dry hillsides in the Edwards Plateau, Rolling Plains, and Cross Timbers and Prairies resource areas (Scifres 1980). The species also occurs in western Oklahoma and in southeastern New Mexico (Correll and Johnston 1970). Redberry juniper originally occupied shallow, rocky sites on northwest exposures and has extended its range onto adjacent slopes and fertile, lowland ranges in the last 100 years (Ellis and Schuster 1968). The accelerated invasion of grasslands and other plant communities by juniper has been caused by overgrazing, reduced frequency and intensity of naturally occurring fires, and possibly by climatic change (Blackburn and Tueller 1970, Ellison 1960, Emerson 1932, Huss 1954, Jameson 1962, Johnsen 1962).

Redberry juniper is a large dioecious or rarely monoecious shrub or small ( $<6 \mathrm{~m}$ high) evergreen tree, usually with numerous stems arising from the crown to form a dense clump (Correll and Johnston 1970). Smith et al. (1975) reported that redberry juniper seedling growth was severely retarded by a good cover of range grasses and that all seedlings died when cut below the axil of the cotyledons.

On some range sites redberry juniper serves as a soil stabilizer, furnishes cover for wildlife, and probably should not be controlled (Scifres 1980). However, forage production is usually seriously

Authors are professor and research associate, Texas Agricultural Experiment Station, Rt. 2, Box 950, 76901. S.G. Whisenant's current address is Dept. of Botany and Range Science, Brigham Young University, Provo, Utah 84602 . The authors wish to express their appreciation to County Extension Agent Clint Langford and Soil Conservation Service District Conservationist Virgil Polochek for assistance in planning, installation, and evaluation of these experiments. Land for this research was provided by the Hudspeth Hospital Ranch. The authors express appreciation to the Sutton County Brush Control Committee for providing funds for equipment and supplies.

This manuscript was approved by the Director, Texas Agricultural Experiment Station as TA-16397.

Manuscript received September 26, 1980. reduced and handling of livestock is severely hampered in dense stands. Litter and foliage extracts of some Juniperus species have allelopathic effects on associated grass and browse species (Jameson 1966, 1970; Lavin et al. 1968).

Chaining, tree-dozing, and root-plowing are used to controlredberry juniper in West Texas (Rechenthin et al. 1964). Sprays of chlorophenoxy acid herbicides, such as 2,4-D [(2,4dichlorophenoxy)acetic acid] and 2,4,5-T [(2,4,5trichlorophenoxy)acetic acid] do not kill rcdbcrry junipcr (Scifres 1972). Pelleted picloram (4-amino-3,5,6-trichloropicolinic acid) applied as individual plant treatments or broadcast at 2.2 to 4.5 $\mathrm{kg} /$ ha active ingredient (a.i.) has effectively controlled mature redberry juniper in the Rolling Plains and Edwards Plateau of Texas (Robison and Cross 1970, Schuster 1976, Scifres 1972). However, aerial applications of picloram at $1.1 \mathrm{~kg} / \mathrm{ha}$ (a.i.) as a foliar spray were not effective (Robison and Cross 1970). The granular formulation of dicamba (3,6-dichloro-o-anisic acid) applied at 3.5 to $7 \mathrm{~g} / \mathrm{m}$ of canopy diameter killed 30 to $40 \%$ of the mature redberry junipers treated, but pelleted monuron [3-(pchlorophenyl)-1,1-dimethylurea] was ineffective (Scifres 1972). Schuster (1976) recorded 74 to $99 \%$ canopy reduction of mature redberry juniper at two growing seasons after treatment with wetting sprays of $227 \mathrm{~g}$ picloram/378.5 liters of oil/water (2:98 v:v) carrier, and 82 to $100 \%$ canopy reduction after treatment with wetting sprays of picloram $+2,4,5-\mathrm{T}(1: 1)$ at $454 \mathrm{~g}(\mathrm{a} . \mathrm{i}) /$.378.5 liters of oil/water (2:98 v:v) carrier in the Rolling Plains of Texas. He found that spring and fall treatments, when soil water availabilities were favorable for plant growth, were more effective than midsummer treatments.

Smith et al. (1975) speculated that redberry juniper seedlings and junvenile trees less than 12 years old could be controlled by fire, based on the position of the sprouting zone in the early years of growth. However, Steuter and Wright (1979) reported only 52\% mortality of redberry juniper seedlings 7 to $30 \mathrm{~cm}$ tall and $25 \%$ mortality of seedlings 31 to $70 \mathrm{~cm}$ tall at 6 months following March burns in the Rolling Plains of Texas.

Aro (1971) reported that burning was the most effective and least expensive method for converting pinyon (Pinus edulis)-juniper (Juniperus spp.) range types to grassland in Colorado, Utah, Arizona, and New Mexico. Jameson (1971) felt that if the cost of the juniper control method was fixed, that older stands with a zero rate of tree-cover change represented the "optimal" stand to select for treatment. However, if cost of control increased with stand age, he recommended young stands as optimal treatment situations. Whitson et al. (1975) reported that control of mature ashe juniper ( $J$. ashei Buchholz) in the Edwards Plateau of Texas was profitable where chaining + dozing, hand cutting, or hand cutting + chaining were used as initial control practices and hand cutting as the maintenance treatment. He reported increased carrying capacities of $20 \%$ to $75 \%$ after ashe juniper control. The pay-back period to recover the investment in brush control and additional cows was 7 to 8 years. Ashe juniper control produced favorable economic returns when the cost of capital did not exceed $10 \%, 15 \%$, and $17 \%$ for 10-yr, 15-yr and 20-yr planning horizons, respectively.

Redberry juniper seedlings rapidly reinfest rangeland in the 
Edwards Plateau of Texas where mature stands have been controlled by tree-dozing or chaining. Stand densities of seedlings often greatly exceed those of the original, mature trees and result in brush problems more severe than the original stand within a decade. This study was initiated in 1977 to identify effective and least cost methods for controlling redberry juniper seedlings in the Edwa rds Plateau of Texas.

\section{Study Area}

The study was conducted on the Hudspeth Hospital Ranch in western Sutton County, Texas. Treatments were applied in a narrow valley range site (Knippe silty clay; Vertic Calciustolls) and in ecotones between the valley range site and adjacent low stony hill sites (Tarrent stony clay; Lithic Calciustolls) where mature juniper had been tree-dozed 2 years earlier. Woody plants on the study area included live oak (Quercus virginiana) and honey mesquite (Prosopis glandulosa var. glandulosa). Buffalograss (Buchloe dactyloides), common curlymesquite (Hilaria belangeri), and sideoats grama (Bouteloua curtipendula) were the most abundant understory species. The climate of Sutton County is warm and arid. Annual precipitation averages $46 \mathrm{~cm}$ but decreases from about 50 $\mathrm{cm}$ on the east to about $38 \mathrm{~cm}$ on the west. About two-thirds of the precipitation occurs from May through October. The topography of western Sutton County is rough and most of the soils a re shallow and rocky, hence effectiveness of precipitation is often low due to runoff. Cattle, sheep, and goats are grazed yearlong on the ranch.

\section{Methods}

Seventeen different individual plant treatments were applied to redberry juniper seedlings in fall 1977 (September 21) and in spring 1978 (June 7) in a completely randomized design. Cultural treatments included hand grubbing to $5-15 \mathrm{~cm}$ deep and cutting with heavy grubbing hoes at the soil surface. Dry herbicide formulations applied by hand at rates equivalent to 2.2 and $4.5 \mathrm{~kg}$ (a.i.)/ ha included pelleted picloram (10\% a.i.), pelleted tebuthiuron $(\mathrm{N}$ (5- [1,1-dimethylethyl]-1,3,4-thiadiazol-2-yl)- $N, N^{\prime}$-dimethylurea) (20\%a.i.), and granular dicamba (5\% a.i.). Herbicides applied with an 11 -liter hand sprayer as $0.5 \%$ (a.i.) wetting sprays in water carrier with $0.125 \%(\mathrm{v} / \mathrm{v})$ surfactant (alkylarylpolyoxyethylene glycols, free fatty acids, and isopropanol) included the triethylamine salt of triclopyr ([(3,5,6-trichloro-2-pyridinyl)oxy]acetic acid), propylene glycol butyl ether esters of 2,4,5-T, the dimethylamine salt of dicamba, the lithium salt of bromacil (5-bromo-3-sec-butyl6-methyluracil), the potassium salt of picloram, and the triethylamine salts of 2,4,5-T + picloram (1:1). The potassium salt of picloram at the same concentration was also applied in a 2:98 (v:v) diesel fuel/water emulsion with $0.125 \%(\mathrm{v} / \mathrm{v})$ surfactant. The isopropylamine salt of glyphosate [ $N$-(phosphonomethyl)glycine] was applied as an $0.5 \%$ (a.i.) wetting spray in a water carrier without adding surfactant. Haxazionone [3-cyclohexyl-6(dimethylamino)-1-methyl-1,3,5-triazine-2,4 (1 H,3H)-dione] was applied at the same concentration in water carrier with $0.25 \%(\mathrm{v} / \mathrm{v})$ surfactant. Each treatment was applied to three replications of eight or nine seedlings. Canopy height and growth stage of each seedling was recorded prior to treatment and each seedling was permanently marked with a steel rod. Three replications of untreated seedlings were similarly measured and marked on each treatment date.

Mortality, canopy height, and an ocular estimate of canopy reduction were recorded for each seedling at one and two growing seasons after treatment. Mortality data (\%) were analyzed by a nalysis of variance after arc sine transformation. Duncan's multiple range test was used to determine differences among treatment means where appropriate.

An associated study was initiated on June 8, 1978, to compare application costs of selected individual plant treatments. Nine 0.4-ha plots were permanently marked for treatment on a low stony hill range site that had been tree-dozed for control of mature redberry juniper about 3 years earlier. Treatments evaluated including hand grubbing to $5-15 \mathrm{~cm}$ deep, application of pelleted picloram (10\%) at $4.5 \mathrm{~kg}$ (a.i.)/ ha as individual-plant treatments, and wetting sprays $(0.5 \%$ a.i.) of picloram in a water carrier with $0.125 \%(\mathrm{v} / \mathrm{v})$ surfactant. Each treatment was applied to three 0.4-ha plots by a team of three workers marking their swaths with paper flags. Data collected included man-hours of labor/plot, numbers of seedlings treated/plot, and $\mathrm{g}$ of pellets of $\mathrm{ml}$ of spray applied/plot. On July 2, 1979, the plots originally treated by hand grubbing and with wetting sprays of picloram were retreated in the same manner and similar data were collected. The live juniper seedlings were counted on the plots originally treated with pelleted picloram, but these plots were not retreated. Averages for labor and volume or weight of herbicides were calculated for each treatment and costs were calculated based on 1979 retail herbicide costs and $\$ 3.00 / \mathrm{hr}$ labor cost.

\section{Results and Discussion}

Redberry juniper seedlings on the study area averaged $34 \mathrm{~cm}$ tall; $41 \%$ of the seedling population was in the needle leaf stage while $59 \%$ of the plants had scale-type leaves. An average of 2.7 seedlings were counted around 35 disturbed areas where a mature juniper had been tree-dozed 2 years earlier. This was believed to be a conservative estimate, since native and seeded grasses were green and relatively tall when juniper seedlings were counted on May 25 , 1977. No seedlings were found around $25 \%$ of the disturbed areas, probably reflecting the dioecious nature of the species. Also, many seedling had established on undisturbed areas between the juniper that had been tree-dozed. Redberry juniper seedling density was especially high beneath canopies of live oak trees in the valley range site, which was attributed to birds dropping juniper seeds while roosting in the live oak trees.

A total of $38 \mathrm{~cm}$ of precipitation was recorded at the Ranch headquarters in 1977 , compared to $61 \mathrm{~cm}$ in 1978 and $23 \mathrm{~cm}$ in 1979. During the 90-day period prior to the September 21, 1977 treat ment date, only $9 \mathrm{~cm}$ of rainfall were received and no rainfall occurred for nearly 150 days after treatment. In contrast, $22 \mathrm{~cm}$ of rain were recorded during the 90-day period prior to the June 7 , 1978, treatment date and $29 \mathrm{~cm}$ were recorded in the 90-day period after treatment.

Spring or fall application of dry formulations of dicamba, tebuthiuron, or picloram did not effectively control redberry juniper seedlings (Table 1). Seedlings were less susceptible to the granular formulation of dicamba than to tebuthiuron or picloram pellets at the rates evaluated. Regardless of rate or date of application of dicamba granules, mortality of junipers was not significantly increased compared to natural mortality. Fall applications of pelleted tebuthiuron killed $28 \%$ and $54 \%$ of the seedlings at 2.2 and 4.5 $\mathrm{kg} / \mathrm{ha}$, respectively, compared to $44 \%$ and $40 \%$ mortality recorded at two growing seasons after spring applications of the two rates, respectively (Table 1). Pelleted picloram applied in fall at 2.2 and $4.5 \mathrm{~kg} / \mathrm{ha}$ killed 43 and $44 \%$ of the juniper seedlings, respectively; spring applications killed $42 \%$ and $61 \%$ respectively, by two growing seasons after application (Table 1). Phytotoxic effects of dry herbicides applied on June 7, 1978 were minimal at 3 months after treatment, even though $29 \mathrm{~cm}$ of rainfall had been received and conditions were favorable for plant growth. Seedling control was not enhanced significantly by doubling the rate of application of dicamba, tebuthiuron, or picloram. Ultimate seedling control with each of these herbicides did not vary significantly among fall and spring treatment dates (Table 1).

Control of redberry juniper seedlings with pelleted picloram in our study was considerably less than reported by Robison and Cross (1970), Scifres (1972), or Schuster (1976) for mature redberry juniper even though precipitation received after treatments were applied in our June 7, 1978 experiment was adequate for activation of the herbicide. The fate and behavior of herbicides in soils is dependent on many soil properties and the chemical properties of the herbicides (Weber 1971, Weber and Weed 1974, Weed 
Table 1. Mean percent mortality of redberry juniper seedlings at the end of one and two growing seasons after application of various indiviudal plant treatments on September 21, 1977, or June 7, 1978, near Sonora, Texas.

\begin{tabular}{|c|c|c|c|c|c|}
\hline \multirow[b]{3}{*}{ Treatments } & \multirow[b]{3}{*}{ Rate } & \multicolumn{3}{|c|}{ September 21,1977} & \\
\hline & & \multicolumn{2}{|c|}{ Months after treatment } & & \\
\hline & & 12 & 25 & 3 & 16 \\
\hline $\begin{array}{l}\text { None } \\
\quad \text { Pelleted herbicides }\end{array}$ & $\mathrm{kg} / \mathrm{ha}$ & $\mid a^{\prime}$ & $3 a$ & $0 \mathrm{a}$ & la \\
\hline $\begin{array}{l}\text { dicamba } \\
\text { dicamba } \\
\text { tebuthiuron } \\
\text { tebuthiuron } \\
\text { picloram } \\
\text { picloram }\end{array}$ & $\begin{array}{l}2.2 \\
4.5 \\
2.2 \\
4.5 \\
2.2 \\
4.5\end{array}$ & $\begin{array}{c}3 \mathrm{a} \\
3 \mathrm{a} \\
30 \mathrm{~b}^{* 2} \\
52 \mathrm{bc} \\
39 \mathrm{~b}^{*} \\
46 \mathrm{bc}^{*}\end{array}$ & $\begin{array}{c}3 \mathrm{a} \\
2 \mathrm{a} \\
28 \mathrm{bc} * \\
54 \mathrm{~cd} \\
43 \mathrm{c}^{*} \\
4 \mathrm{c}^{*}\end{array}$ & $\begin{array}{l}0 \mathrm{a} \\
\text { la } \\
1 \mathrm{a} \dagger \\
5 \mathrm{ab} \\
1 \mathrm{a}^{\dagger} \\
1 \mathrm{a}^{\dagger}\end{array}$ & $\begin{array}{l}8 a b \\
14 a-c \\
44 e-g^{*} \\
40 c-f \\
42 d-d f^{*} \\
61 \mathrm{fg}^{*}\end{array}$ \\
\hline $\begin{array}{l}\quad \text { Foliar sprays } \\
\text { triclopyr } \\
2,4,5-T \\
\text { glyphosate } \\
\text { dicamba } \\
\text { hexazinonc } \\
\text { bromacil } \\
2,4,5-T+\text { picloram }(1: 1) \\
\text { picloram } \\
\text { picloram }+2 \% \text { diesel fuel }\end{array}$ & $\begin{array}{c}\text { \% a.i. } \\
0.5 \\
0.5 \\
0.5 \\
0.5 \\
0.5 \\
0.5 \\
0.5 \\
0.5 \\
0.5\end{array}$ & $\begin{array}{c}1 \mathrm{a} \\
5 \mathrm{a} \\
32 \mathrm{~b} \\
72 \mathrm{c}^{*} \\
100 \mathrm{~d} \\
100 \mathrm{~d} \\
100 \mathrm{~d} \\
100 \mathrm{~d} \\
100 \mathrm{~d}\end{array}$ & $\begin{array}{c}1 \mathrm{a} \\
16 \mathrm{ab} \\
39 \mathrm{bc} \\
76 \mathrm{~d}^{*} \\
100 \mathrm{e} \\
100 \mathrm{e} \\
99 \mathrm{e} \\
100 \mathrm{e} \\
100 \mathrm{e}\end{array}$ & $\begin{array}{c}16 \mathrm{bc} \\
23 \mathrm{c} \\
20 \mathrm{c} \\
100 \mathrm{~d} \dagger \\
100 \mathrm{~d} \\
95 \mathrm{~d} \\
100 \mathrm{~d} \\
100 \mathrm{~d} \\
100 \mathrm{~d}\end{array}$ & $\begin{array}{l}16 \mathrm{a}-\mathrm{d} \\
23 \mathrm{~b}-\mathrm{e} \\
74 \mathrm{~g} \\
100 \mathrm{~h} \dagger \\
100 \mathrm{~h} \\
100 \mathrm{~h} \\
100 \mathrm{~h} \\
100 \mathrm{~h} \\
100 \mathrm{~h}\end{array}$ \\
\hline \multicolumn{6}{|l|}{ Cultural treatments } \\
\hline $\begin{array}{l}\text { Hand grub } \\
\text { Cut at soil surface }\end{array}$ & - & $\begin{array}{l}100 \mathrm{~d} \\
100 \mathrm{~d}\end{array}$ & $\begin{array}{l}100 \mathrm{e} \\
100 \mathrm{e}\end{array}$ & $\begin{array}{l}100 \mathrm{~d} \\
100 \mathrm{~d}\end{array}$ & $\begin{array}{l}100 \mathrm{~h} \\
100 \mathrm{~h}\end{array}$ \\
\hline
\end{tabular}

'Means within a column followed by similar letters are not significantly different at $P<0.05$ according to Duncan's multiple range test.

2 Means within a row followed by similar symbol superscripts are not significantly different at $P<0.05$ according to Duncan's multiple range test.

and Weber 1974).

Foliar sprays of triclopyr killed $16 \%$ or fewer of the redberry juniper seedlings at two growing seasons after fall or spring applications, while $2,4,5-\mathrm{T}$ controlled only 16 to $23 \%$ of the seedlings at the two seasons, respectively (Table 1). There was a tendency for glyphosate applications in the spring to control more juniper seedlings than applications in the fall (74\% vs. $39 \%)$, possibly a function of better conditions for plant growth in the spring.

Foliar sprays of dicamba applied in June 1978 completely controlled redberry juniper seedlings within 3 months, which was significantly better than the mortality recorded 25 months following September 1977 treatments when soil water availabilities were very low (Table 1).

Foliar sprays of hexazinone, bromacil, and picloram in water carrier and picloram in the diesel fuel/water emulsion carrier (2:98 v:v) controlled $100 \%$ of the redberry juniper seedlings within 3 to 25 months after application in fall or spring (Table 1). Adding diesel fuel to the carrier for picloram sprays was not necessary for effective control. The foliar spray of 2,4,5-T + picloram controlled $99 \%$ of the seedlings treated in September 1977, and $100 \%$ of those treated in June 1978 . Herbicidal effects of wetting sprays $(0.5 \%$ a.i.) of dicamba, hexazinone, bromacil, 2,4,5-T + picloram (1:1), and picloram were manifested within 3 months following fall and spring treatments.

An average of $60 \mathrm{ml}$ of herbicide solution were required to wet the foliage of each redberry juniper seedling in these experiments, hence each 3.8 liters of herbicide mixture treated about 63 seedlings.

Hand grubbing to $5-15 \mathrm{~cm}$ deep or cutting at the soil surface controlled $100 \%$ of the juniper seedlings, regardless of treatment date. None of the grubbed or severed seedlings had resprouted at 16 to 25 months after treatment, confirming earlier observations that the cotyledonary node of redberry juniper seedlings is above the soil surface and the species does not sprout from root tissue (Smith et al. 1975).

Mortality among untreated seedlings averaged $1 \%$ to $3 \%$ during

Table 2. Labor (man-hr/ha), volume (liters/ha) of herbicide solution or weight (g/ha) of pelleted formulation required for treating various densities of redberry juniper seedlings as individual-plant treatments.

\begin{tabular}{|c|c|c|c|c|c|c|c|c|}
\hline \multirow[b]{3}{*}{ Treatment } & \multicolumn{4}{|c|}{ Original treatment (June 8,1978 ) } & \multicolumn{4}{|c|}{ Follow-up treatment (July 2. 1979) } \\
\hline & \multirow{2}{*}{$\begin{array}{l}\text { Seedling density } \\
\text { (no./ha) }\end{array}$} & \multirow{2}{*}{$\begin{array}{c}\text { Labor } \\
\text { (man-hr/ha) }\end{array}$} & \multicolumn{2}{|c|}{ Herbicide } & \multirow{2}{*}{$\begin{array}{l}\text { Seedling density } \\
\text { (no/ha) }\end{array}$} & \multirow{2}{*}{$\begin{array}{c}\text { Labor } \\
\text { (man-hr/ha) }\end{array}$} & \multicolumn{2}{|c|}{ Herbicide } \\
\hline & & & (liters/ha) & (g/ha) & & & (liters/ha) & (g ha) \\
\hline Hand grub@5 to $15 \mathrm{~cm}$ & $\begin{array}{r}736 \\
1,166 \\
2,409\end{array}$ & $\begin{array}{l}4.0 \\
4.0 \\
5.2\end{array}$ & $\begin{array}{l}- \\
-\end{array}$ & $\begin{array}{l}- \\
-\end{array}$ & $\begin{array}{l}388 \\
400 \\
541\end{array}$ & $\begin{array}{l}3.8 \\
3.3 \\
3.0\end{array}$ & - & $\begin{array}{l}- \\
-\end{array}$ \\
\hline $\begin{array}{l}\text { Pelleted picloram } \\
(10 \%) @ 4.48 \mathrm{~kg} / \mathrm{ha}\end{array}$ & $\begin{array}{r}336 \\
1,090 \\
1,035\end{array}$ & $\begin{array}{l}2.2 \\
2.6 \\
2.7\end{array}$ & - & $\begin{array}{r}445 \\
1,137 \\
778\end{array}$ & $\begin{array}{l}343^{\prime} \\
556^{\prime} \\
544^{\prime}\end{array}$ & - & $\begin{array}{l}- \\
- \\
-\end{array}$ & $\begin{array}{l}- \\
-\end{array}$ \\
\hline $\begin{array}{l}\text { Picloram foliar } \\
\text { spray }(0.5 \% \text { a.i. })\end{array}$ & $\begin{array}{r}840 \\
1,265 \\
2,424\end{array}$ & $\begin{array}{l}4.6 \\
4.5 \\
5.8\end{array}$ & $\begin{array}{l}32.9 \\
41.7 \\
45.1\end{array}$ & $\begin{array}{l}- \\
- \\
-\end{array}$ & $\begin{array}{r}415 \\
410 \\
1,149\end{array}$ & $\begin{array}{l}2.0 \\
1.7 \\
2.9\end{array}$ & $\begin{array}{l}17.5 \\
11.6 \\
25.6\end{array}$ & - \\
\hline
\end{tabular}

No follow-up control treatments were applied to these plots. 
Table 3. Costs (\$/ha) of selected individual-plant treatments for treating various population densities of redberry juniper seedlings.

\begin{tabular}{|c|c|c|c|c|c|c|c|c|c|}
\hline \multirow[b]{2}{*}{ Treatments } & \multicolumn{4}{|c|}{ Original treatment (June 8,1978 ) } & \multicolumn{4}{|c|}{ Follow-up treatment (July 2, 1979) } & \multirow[b]{2}{*}{$\begin{array}{c}\text { Total Cost } \\
\text { (\$/ha) }\end{array}$} \\
\hline & $\begin{array}{c}\text { Seedling } \\
\text { density } \\
\text { (no./ha) }\end{array}$ & $\begin{array}{l}\text { Laborl } \\
(\$ / \text { ha })\end{array}$ & $\begin{array}{c}\text { Herbicide } \\
\text { (\$/ha) }\end{array}$ & $\begin{array}{c}\text { Sub-total } \\
(\$ / \text { ha })\end{array}$ & $\begin{array}{l}\text { Seedling } \\
\text { density } \\
\text { (no./ha) }\end{array}$ & $\begin{array}{l}\text { Labor } \\
\text { (\$/ha) }\end{array}$ & $\begin{array}{c}\text { Herbicide } \\
(\$ / \text { ha })\end{array}$ & $\begin{array}{c}\text { Sub-total } \\
(\$ / \text { ha })\end{array}$ & \\
\hline Hand grub@5 to $15 \mathrm{~cm}$ & $\begin{array}{r}736 \\
1,166 \\
2,409\end{array}$ & $\begin{array}{r}\$ 11.85 \\
11.85 \\
15.57\end{array}$ & - & $\begin{array}{r}\$ 11.85 \\
11.85 \\
15.57\end{array}$ & $\begin{array}{l}388 \\
400 \\
541\end{array}$ & $\begin{array}{r}\$ 11.37 \\
9.87 \\
8.91\end{array}$ & $\frac{-}{-}$ & $\begin{array}{r}\$ 11.37 \\
9.87 \\
8.91\end{array}$ & $\begin{array}{c}\$ 23.22 \\
21.72 \\
24.48\end{array}$ \\
\hline $\begin{array}{l}\text { Pelleted picloram } \\
\qquad(10 \% \text { ai.i })^{2}\end{array}$ & $\begin{array}{r}336 \\
1,090 \\
1,035\end{array}$ & $\begin{array}{r}\$ 6.66 \\
7.77 \\
8.16\end{array}$ & $\begin{array}{r}\$ 2.45 \\
6.26 \\
4.29\end{array}$ & $\begin{array}{r}\$ 9.11 \\
14.03 \\
12.45\end{array}$ & $\begin{array}{l}343^{4} \\
556^{4} \\
544^{4}\end{array}$ & - & - & $\begin{array}{l}- \\
- \\
-\end{array}$ & $\begin{array}{r}\$ 9.11^{5} \\
14.03^{5} \\
12.45^{5}\end{array}$ \\
\hline $\begin{array}{l}\text { Picloram foliar spray } \\
(0.5 \% \text { a.i. })^{3}\end{array}$ & $\begin{array}{r}840 \\
1,265 \\
2,424\end{array}$ & $\begin{array}{r}\$ 13.71 \\
13.35 \\
17.43\end{array}$ & $\begin{array}{r}\$ 12.93 \\
16.39 \\
17.72\end{array}$ & $\begin{array}{r}\$ 26.64 \\
29.74 \\
35.15\end{array}$ & $\begin{array}{r}415 \\
410 \\
1,149\end{array}$ & $\begin{array}{r}\$ 5.94 \\
4.95 \\
8.64\end{array}$ & $\begin{array}{c}\$ 6.86 \\
4.56 \\
10.05\end{array}$ & $\begin{array}{r}\$ 12.80 \\
9.51 \\
18.69\end{array}$ & $\begin{array}{r}\$ 39.44 \\
39.25 \\
53.84\end{array}$ \\
\hline
\end{tabular}

Labor costs calculated at $\$ 3.00 \mathrm{hr}$.

'Cost calculated at $\$ 5.51 \mathrm{~kg}$ bulk pellets $(\$ 2.50, \mathrm{lb}$.

'Cost calculated at $\$ 16.91$ liter $(\$ 64.00$ /gal.).

+ No follow-up treatments were applied to these plots

sTotal cost does not include a follow-up treatment.

this study. Untreated seedlings averaged $37 \mathrm{~cm}$ tall in September 1977 and $45 \mathrm{~cm}$ tall in October 1979, a 22\% increase in canopy height during two growing seasons $(n=50)$. Canopy height of untreated seedlings marked in June 1978 increased $27 \%$ during two growing sea sons (from 30 to $38 \mathrm{~cm} ; n=50$ ). Thus redberry juniper seedlings of the sizes observed in this study were well adapted for growth and survival under the semiarid conditions of West Texas.

An average of 1,256 seedlings/ ha were trea ted on the nine 0.4 -ha plots on June 8, 1978 (range 336 to $2,424 /$ ha). Hand grubbing required from 4 man-hr labor/ha for a seedling density of $736 /$ ha to $5.2 \mathrm{man}-\mathrm{hr} /$ ha for a seedling density of $2,409 /$ ha (Table 2 ) for a cost of from $\$ 11.85 /$ ha to $\$ 15.57 /$ a (Table 3 ).

Application of pelleted picloram to individual seedlings required less labor than did hand grubbing; 2.2 man-hr/ha for treating 336 seedlings and $2.7 \mathrm{man}-\mathrm{hr} /$ ha for treating 1,035 seedlings (Table 2). About $445 \mathrm{~g}$ / ha of pelleted picloram (bulk basis) was used to treat 336 seedlings compared to $1,137 \mathrm{~g} /$ ha to treat 1,090 seedlings. The rate of pelleted herbicide actually applied (about $1 \mathrm{~g} /$ seedlings) exceeded the intended rate $(0.4 \mathrm{~g} /$ seedling $)$, but the actual rate was used for calculating costs for this treatment (Tables 2 and 3). Total costs for treating redberry juniper seedlings with pelleted picloram ranged from $\$ 9.11$ / ha to $\$ 14.03$ / ha (Table 3 ).

Application of wetting foliar sprays of picloram to individual juniper seedlings was considerably more time-consuming than hand grubbing or applying pelleted herbicide. Treating 840 seedlings ha required $4.6 \mathrm{man}$-hr labor compared to $5.8 \mathrm{man}-\mathrm{hr} / \mathrm{ha}$ for

Table 4. Estimated average total costs (\$/ha) for initial and follow-up individual plant treatments for control of redberry juniper seedlings.

\begin{tabular}{|c|c|c|c|}
\hline \multirow[b]{2}{*}{ Treatments } & \multicolumn{3}{|c|}{ Costs (\$/ha) } \\
\hline & Labor & Herbicide & Total \\
\hline Cut at soil surface & $\$ 23.14$ & 一 & $\$ 23.14$ \\
\hline Hand grub at 5 to $15 \mathrm{~cm}$ & $\$ 23.14$ & - & $\$ 23.14$ \\
\hline $\begin{array}{l}\text { Dicamba' foliar spray } \\
(0.5 \% \text { a.i. })\end{array}$ & $\$ 21.34$ & $\$ 6.89$ & $\$ 28.24$ \\
\hline $\begin{array}{l}\text { Bromacil2 foliar spray } \\
(0.5 \% \text { a.i. })\end{array}$ & $\$ 21.34$ & $\$ 7.93$ & $\$ 29.28$ \\
\hline $\begin{array}{l}\text { Hexazinone } e^{3} \text { foliar spray } \\
(0.5 c i c \text { a.i. })\end{array}$ & $\$ 21.34$ & $\$ 10.75$ & $\$ 32.10$ \\
\hline $\begin{array}{l}2.4 .5-\mathrm{T}+\text { picloram }(1: 1)^{4} \\
\quad \text { foliar spray }(0.5 C / / \text { a.i. })\end{array}$ & $\$ 21.34$ & $\$ 11.09$ & $\$ 32.44$ \\
\hline Picloram foliar spray $(0.5 \%$ a.i. $)$ & $\$ 21.34$ & $\$ 22.84$ & $\$ 44.18$ \\
\hline
\end{tabular}

'Cost calculated at $\$ 9.71$ liter $(\$ 36.75$ gal.)

:Cost calculated at $\$ 6.01$ liter $(\$ 22.75 \mathrm{gal}$.$) .$

'Cost calculated at $\$ 33.07 \mathrm{~kg}(\$ 15 \mathrm{lb}$.)

+ Cost calculated at $\$ 8.19$ liter $(\$ 31.00 \mathrm{gal}$.). treating 2,424 seedling/ha. Volume of herbicide mixture used ranged from 33 liters/ha to 45 liters/ha (Table 2) and total costs ranged from $\$ 26.64 /$ ha to $\$ 35.15 /$ ha for low and high seedling densities, respectively (Table 3). Average volume of herbicide mixture applied was $26 \mathrm{ml} /$ seedling, only about $44 \%$ as much as was applied in the experiments discussed above. The difference was duc to the smaller canopies of seedlings or the low stony hill site compared to the valley range site.

Numerous redberry juniper seedlings were still alive on all trcated plots at 1 year after treatment. Consequently, the handgrubbed plots and those originally treated with wetting sprays of picloram were retreated only July 2,1979 . The plots originally treated with pelleted picloram were not retreated because of the relatively poor control from this treatment in the experiments described above. However, live seedlings were counted in all three replications. An average stand density of 527 seedlings/ha had been missed or not killed by the original treatments. None of the seedlings counted on July 2, 1979, were less than 1 year old. An average of $26 \%$ of the seedlings had been missed during hand grubbing, compared to $30 \%$ in the plots treated with foliar sprays of picloram. An average of $40 \%$ of the seedlings in plots originally treated with pelleted picloram were either missed or had not died (Table 2).

Follow-up treatment by hand grubbing required 3 to 3.8 man$\mathrm{hr} /$ ha to control stand densities of 541 and $388 / \mathrm{ha}$, respectively (Table 2). The follow-up hand grubbing cost from $\$ 8.91 /$ ha to $\$ 11.37 /$ ha, bringing the total cost of initial and follow-up treatments to $\$ 21.72$ to $\$ 24.48 /$ ha (Table 3 ).

Follow-up treatment with picloram foliar spray required from $1.7 \mathrm{man}-\mathrm{hr} /$ ha to treat 410 seedlings/ha to $2.9 \mathrm{man}-\mathrm{hr} /$ ha to treat 1,149 seedling/ha (Table 2). Total costs for initial and follow-up treatments with picloram foliar sprays ranged from $\$ 39.25$ to $\$ 53.84 /$ ha (Table 3 ).

Estimated costs for applying other treatments that effectively controlled redberry juniper seedlings in the first phase of this study were calculated based on labor and actual herbicide volume used in the latter phase of this study (Table 4). Cutting at the soil surface and hand grubbing were the "least cost" methods at $\$ 23.14 /$ ha. It was assumed that cutting would require essentially the same amount of labor as hand grubbing, especially if grubbing was conducted when soils were moist. Dicamba was the least cost herbicide spray at $\$ 28.24$ / ha followed closely by bromacil at $\$ 29.28 /$ ha. Foliar sprays of hexazinone and $2,4,5-\mathrm{T}+$ picloram (1:1) ranked fifth and sixth as alternative methods, with average estimated costs of $\$ 32.10 /$ ha and $\$ 32.44 /$ ha, respectively. The picloram foliar spray was most expensive of the treatments that effectively controlled redberry juniper seedlings, with an average cost of $\$ 44.18 /$ ha. 


\section{Summary and Conclusions}

Redberry juniper seedling densities averaged more than $2,000 /$ ha on low stony hill range sites in the Edwards Plateau where mature junipers had been controlled by tree-dozing 3 years earlier. Juniper seedlings pose a serious threat to future range forage production and livestock management. Individual-plant treatments that consistently controlled seedlings in fall or spring included cutting at the soil surface; hand grubbing; and $0.5 \%$ foliar sprays of bromacil, hexazinone, $2,4,5-\mathrm{T}+$ piclora $\mathrm{m}$ (1:1) or picloram in water carriers; and picloram in a 2:98 (v:v) diesel fuel/water emulsion. Foliar sprays of dicamba applied in spring completely controlled juniper seedlings, but fall treatments killed only $76 \%$ of the seedlings treated. Individual plant treatments with granular dicamba, pelleted tebuthiuron and pelleted picloram at 2.2 to 4.5 $\mathrm{kg}$ (a.i.)/ha did not effectively control redberry juniper seedlings under these environmental conditions. Pelleted picloram ( $10 \%$ a.i.) at $4.5 \mathrm{~kg}$ (a.i.)/ ha, as an individual plant treatment or broadcast applications, is the only herbicide currently approved for control of redberry juniper in Texas.

Cutting at ground line and hand grubbing were the least cost alternatives $(\$ 23.14 / \mathrm{ha})$. Although individual seedling treatment with pelleted picloram costs no more than hand methods, application during the spring, immediately prior to precipitation considered adequate for activation of the herbicide did not effectively control juniper seedlings. Foliar spray of dicamba was the least costly of the herbicide sprays evaluated $(\$ 28.24 /$ ha $)$, followed closely by bromacil $(\$ 29.28 / \mathrm{ha})$, hexazinone $(\$ 32.10 / \mathrm{ha})$, and 2,4,5-T + picloram (1:1) (\$32.44/ ha).

inousands of hectares of Edwards Plateau rangeland have been tree-dozed or chained to control mature redberry juniper stands. Dense stands or juniper seedlings are reinfesting these areas at an alarming pace. Resource managers must decide whether to control stands of seedlings or to wait until junipers are mature and seriously reducing forage production. Control of mature redberry juniper by chaining two ways costs from $\$ 17$ to $\$ 24 /$ ha (1979 prices). On the Hudspeth Hospital Ranch in Sutton County, Texas, control of mature redberry juniper in 1978 by tree-dozing and seeding the disturbed areas cost $\$ 88.61 / \mathrm{ha}, 45 \%$ of which was cost-shared under the Soil Conservation Service Great Plains Conservation Program. The net cost to the Ranch for this range improvement was $\$ 48.65 /$ ha. Controlling redberry juniper seedlings by hand cutting, grubbing, or with foliar sprays of dicamba, bromacil, hexazinone, or 2,4,5-T + picloram offers resource managers effective alternatives for preventing range deterioration as juniper seedlings mature.

\section{Literature Cited}

Allred, B.W. 1949. Distribution and control of several woody plants in Texas and Oklahoma. J. Range Manage. 2:17-29.

Allred, B.W. 1964. Problems and opportunities on U.S. grasslands. Amer. Hereford J. 54:70-72, 134.

Aro, R.S. 1971. Evaluation of pinyon-juniper conversion to grassland. J. Range Manage. 24:188-197.
Blackburn, W.H., and P.T. Tueller. 1970. Pinyon and juniper invasion in black sagebrush communities in east-central Nevada. Ecology 51:841848.

Correll, D.S., and M.C. Johnston. 1970. Manual of the vascular plants of Texas. Texas Res. Foundation. Renner. Texas. 1881 p.

Ellis, D., and J.L. Schuster. 1968. Juniper age and distribution on an isloated butte in Garza County, Texas. Southwestern Natur. 13:343-348.

Ellison, L. 1960. Influence of grazing on plant succession of rangelands. Bot. Rev. 26:1-78.

Emerson, F.W. 1932. The tension zone between the grama grass and pinyon juniper associations in northeastern New Mexico. Ecology 13:347-358.

Huss, D.L. 1954. Factors influencing plant succession following fire in ashe juniper woodland types in Real County, Texas. J. Range Manage. 7:244.

Jameson, D.A. 1962. Effects of burning on a galleta-black grama range invaded by juniper. Ecology 43:760-763.

Jameson, D.A. 1966. Pinyon-juniper litter reduces growth of blue grama. J. Range Manage. 10:214-217.

Jameson, D.A. 1970. Degradation and accumulation of inhibitory substance from Juniperus osteosperma (Torr.) Little. Plant and Soil 33:212224.

Jameson, D.A. 1971. Optimum stand selection for juniper control on southwestern woodland ranges. J. Range Manage. 24:94-99.

Johnsen, T.N. 1962. One-seed juniper invasion of northern A rizona grasslands. Ecol. Monogr. 32:187-207.

Lavin, F., D.A. Jameson and F.B. Gomm. 1968. Juniper extract and deficient aeration effects on germination of six range species. J. Range Manage. 21:262-263.

Rechenthin, C.A., H.M. Bell, R.J. Pederson, and D.B. Polk. 1964. Grassland restoration, part 2, brush control. U.S. Dep. Agr. Soil Conserv. Serv. Temple, Texas. $39 \mathrm{p}$.

Robison, E.D., and B.T. Cross. 1970. Redberry juniper control and grass response following aerial application of picloram. p. 20-22. In: Brush Research in Texas, 1970. Texas Agr. Exp. Sta. Consol. PR-2801-2828.

Schuster, J.L. 1976. Redberry juniper control with picloram. J. Range Manage. 29:490-491.

Scifres, C.J. 1972. Redberry juniper control with soil-applied herbicides. J. Range Manage. 25:308-310.

Scifres, C.J. 1980. Brush Management Principles and Practices for Texas and the Southwest. Texas A\&M Univ. Press. College Station. 360 p.

Smith, H.N., and C.A. Rechenthin. 1964. Grassland restoration, part 1 , the Texas brush problem. U.S. Dep. Agr., Soil Conserv. Serv. Temple, Texas. $33 \mathrm{p}$

Smith, M.A., H.A. Wright, and J.L. Schuster. 1975. Reproductive characteristics of redberry juniper. J. Range Manage. 28:126-128.

Steuter, A.A., and H.A. Wright. 1979. Redberry juniper mortality following prescribed burning. Texas Tech Univ. Research Highlight Noxious Brush and Weed Control Range and Wildl. Manage. -1979. 10:14.

Weber, J.B. 1971. Interactions of organic pesticides with particulate matter in aquatic and soil systems. p. 55-120. In: R.F. Gould (ed.). Fate of Organic Pesticides in the Aquatic Environment. Amer. Chem. Soc., Washington, D.C.

Weber, J.B., and S.B. Weed. 1974. Effects of soil on the biological activity of pesticides. p. 223-256. In: W.D. Guenzi (ed.). Pesticides in soil and water, Soil Sci. Am., Madison, Wis.

Weed, S.B., and J.B. Weber. 1974. Pesticide-organic interactions. Pages 39-66, In: W.D. Guenzi (ed.). Pesticides in soil and water. Soil Sci. Soc. Am., Madison, WI.

Whitson, R.E., C.J. Scrifes, and D.B. Polk, Jr. 1975. Economic efficiency of ashe juniper control in the Edwards Plateau. p. 59-60, $/ \mathrm{n}$ : Rangeland Resources Res. 1971-74. Texas Agr. Exp. Sta. PR-3341. 